\title{
GAYA HIDUP DAN STATUS GIZI SERTA HUBUNGANNYA DENGAN DIABETES MELITUS PADA WANITA DEWASA DI DKI JAKARTA
}

\author{
Siti Nuryati'; Siti Madanijah ${ }^{1} ;$ Atmarita $^{2}$ dan Hardinsyah ${ }^{1}$ \\ 'Departemen Gizi Masyarakat, Fakultas Ekologi Manusia, IPB \\ ${ }^{2}$ Badan Penelitian dan Pengembangan Kesehatan, Depkes RI
}

\section{ABSTRACT \\ LIFE STYLE AND NUTRITIONAL STATUS AND THEIR ASSOCIATION WITH DIABETES MELLITUS ON WOMEN IN JAKARTA}

There is an increasing trend in the prevalence of diabetes mellitus in both developing countries including Indonesia. The research aimed to analyze the relationships between life style, nutritional status, and socio-economic and demographic factors with diabetes mellitus. Data used for the study are secondary data from the Basic Health Research (Riskesdas 2007), which applied a cross-sectional study design. The number of samples obtained 5702 adult women with inclusion criteria aged $\geq 20$ years and not pregnant. The results show, the risk factors for diabetes mellitus are age $\geq 45$ years on women with obesity $(\mathrm{OR}=13.0)$; age $\geq 45$ years on women without obesity $(\mathrm{OR}=9.3)$. and sugary food consumption. The results imply the important of managing diet in preventing diabetes mellitus for women in Jakarta.

Keywords: life style, nutritional status, diabetes mellitus, obesity

\section{PENDAHULUAN}

$\mathrm{D}$ abetes melitus merupakan penyakit tidak menular yang prevalensinya cukup tinggi di dunia. Badan Kesehatan Dunia (WHO) tahun 2003 menyebutkan, penderita diabetes melitus angkanya mencapai 194 juta jiwa atau 5,1 persen dari penduduk dunia usia dewasa dan pada tahun 2025 diperkirakan meningkat menjadi 333 juta jiwa'.

$\mathrm{Di}$ Indonesia, penderita diabetes melitus telah mencapai angka 8,4 juta jiwa pada tahun 2000 dan diperkirakan menjadi sekitar 21,3 juta jiwa pada tahun $2020^{2}$. Tingginya jumlah penderita tersebut menjadikan Indonesia menempati urutan keempat dunia setelah Amerika Serikat, India dan China (Diabetes Care, 2004) ${ }^{3}$. Berdasar SKRT (2001), prevalensi diabetes melitus di Indonesia sebesar 7,5 persen ${ }^{4}$. SKRT (2003) melaporkan prevalensinya sebesar 10,4 persen ${ }^{5}$. Laporan Hasil Riskesdas (2008) menunjukkan prevalensi nasional diabetes melitus sebesar 1,1 persen ${ }^{6}$.

Faktor sosial ekonomi, serta adanya perubahan gaya hidup diduga telah menyebabkan peningkatan besaran kasuskasus penyakit tidak menular di Indonesia, termasuk dalam hal ini diabetes melitus. Perilaku makan yang tidak sehat seperti tinggi lemak, kurang sayur dan buah, makanan asin, makanan manis, kebiasaan merokok, konsumsi alkohol, stres, serta minimnya aktivitas fisik merupakan faktorfaktor risiko penyakit degeneratif, disamping faktor-faktor risiko lain seperti usia, jenis kelamin dan keturunan.

Meskipun secara nasional, berdasar Laporan Hasil Riskesdas (2008) telah diketahui prevalensi diabetes melitus berikut analisis faktor-faktor risikonya, namun adanya sebuah studi yang mengkaji dan menganalisis faktor-faktor risiko diabetes melitus di tingkat daerah (provinsi) masih perlu dilakukan. Hal ini untuk memberikan gambaran yang lebih jelas dari kejadian penyakit degeneratif tersebut sampai ke tingkat daerah (provinsi) dengan harapan dapat segera disusun upaya (kebijakan) penanggulangan, prioritas deteksi dini, serta pencegahan di tingkat daerah. Hal ini menjadi sangat relevan seiring dengan otonomi daerah yang menekankan kebijakan pembangunan, termasuk pembangunan 
bidang gizi dan kesehatan yang dikonsentrasikan di daerah (desentralisasi). Berdasarkan hal tersebut di atas, penelitian ini bertujuan untuk mengkaji dan menganalisis hubungan gaya hidup dan status gizi dengan terhadap kejadian diabetes melitus pada wanita dewasa di DKI Jakarta.

\section{METODA PENELITIAN}

Penelitian ini menggunakan data sekunder yang bersumber dari hasil
Riskesdas 2007. Riskesdas 2007 menggunakan disain penelitian crosssectional. Dalam penelitian ini ditetapkan kriteria inklusi yaitu sampel pria DKI Jakarta berusia $\geq 20$ tahun, sehingga didapatkan jumlah sampel sebesar 5132 sampel. Setelah dilakukan cleaning terhadap data awal kemudian dilakukan pengolahan dan analisis data.

Tabel 1

Pengkategorian Variabel Penelitian

\begin{tabular}{|c|c|}
\hline Variabel & Kategori pengukuran \\
\hline Umur & $\geq 45$ dan $<45$ \\
\hline Status sosial ekonomi & Tinggi dan rendah \\
\hline Diabetes Melitus & (1)Diagnosis tenaga kesehatan, (2)gejala \\
\hline \multirow[t]{2}{*}{ Status Gizi } & (1)Indeks Massa Tubuh/IMT (kurus, normal, gemuk, obes) \\
\hline & (2)Lingkar perut (pria berisiko $>90 \mathrm{~cm}$, wanita $>80 \mathrm{~cm})^{8}$ \\
\hline $\begin{array}{l}\text { Konsumsi jeroan } \\
\text { Konsumsi makanan berlemak } \\
\text { Konsumsi makanan asin }\end{array}$ & Sering( $\geq 1$ kali/hari) dan jarang(<1kali/hari) \\
\hline \multicolumn{2}{|l|}{ Konsumsi makanan awetan } \\
\hline \multicolumn{2}{|l|}{ Konsumsi makanan/minuman manis } \\
\hline \multicolumn{2}{|l|}{$\begin{array}{l}\text { Konsumsi minuman berkafein } \\
\text { Konsumsi gabungan }\end{array}$} \\
\hline \multirow[t]{2}{*}{ Merokok } & $\begin{array}{l}\text { (1)Riwayat (merokok setiap hari, kadang-kadang, dulu } \\
\text { pernah merokok, tidak pernah merokok); } \\
\text { (2)Umur pertama kali merokok ( }<17 \text { th dan } \geq 17 \text { th) }\end{array}$ \\
\hline & $\begin{array}{l}\text { (3)Jumlah batang yang dihisap/hari ( } \geq 15 \mathrm{btg} \text { dan }<15 \mathrm{btg} \text { ) } \\
\text { (4)Jenis rokok }\end{array}$ \\
\hline \multirow[t]{3}{*}{ Konsumsi alkohol } & (1)Konsumsi 1 bulan terakhir (ya dan tidak) \\
\hline & (2)Frekuensi (sering ( $\geq 5$ hari/minggu) dan jarang) \\
\hline & $\begin{array}{l}\text { (3)Porsi ( }>2 \text { satuan dan } \leq 2 \text { satuan), } \\
\text { (4)Jenis alkohol }\end{array}$ \\
\hline Gangguan mental emosional & Gangguan ( $\geq 6$ jawaban ya) dan normal (<6 jawaban ya) \\
\hline \multirow[t]{2}{*}{ Konsumsi buah dan sayur } & $\begin{array}{l}\text { (1)Cukup ( } \geq 5 \text { porsi/hari selama } 7 \text { hari/minggu) } \\
\text { dan tidak cukup, } \\
\text { (2)Frekuensi ( } \geq 3 \text { hari/minggu dan }<3 \text { hari/minggu), }\end{array}$ \\
\hline & (3)Porsi( $\geq 3$ porsi/hari dan $<3$ porsi/hari) \\
\hline Aktivitas fisik & $\begin{array}{l}\text { Cukup (aktivitas berat/sedang/ringan minimal } 10 \text { menit, } \\
\text { selama } \geq 5 \text { hari/minggu, dan total waktu } \geq 150 \\
\text { menit/minggu) } \\
\text { dan tidak cukup }\end{array}$ \\
\hline
\end{tabular}


Data yang digunakan dalam penelitian ini meliputi jenis kelamin, umur, jenjang pendidikan, pekerjaan utama, pengeluaran per kapita/bulan, berat badan, tinggi badan, lingkar perut, diagnosis diabetes melitus, gejala diabetes melitus, dan data seputar gaya hidup yang meliputi perilaku konsumsi buah dan sayur, konsumsi jeroan, makanan berlemak, makanan asin, makanan yang diawetkan, makanan/minuman manis, minuman berkafein, aktivitas fisik, gangguan mental emosional, kebiasaan merokok, dan konsumsi alkohol. Berbagai variabel penelitian dikategorikan sebagaimana disajikan dalam Tabel 1 berikut:

Analisis data dilakukan dengan univariat, bivariat dan multivariat. Analisis univariat untuk memperoleh gambaran distribusi frekuensi karakteristik responden. Sedangkan analisis bivariat untuk melihat faktor determinan diabetes melitus. Uji Chisquare dilakukan dengan batas kemaknaan 0.05. Analisis multivariat dilakukan untuk menarik kesimpulan akhir penelitian. Analisis menggunakan multiple logistic regression.

\section{HASIL}

Karakteristik Sampel menurut Kondisi Sosial Ekonomi dan Demografi

Sampel penelitian ini sebanyak 5702 wanita dewasa yang memenuhi kriteria sampel. Gambaran karakteristik sampel menurut kondisi sosial ekonomi dan demografi dapat dilihat pada Tabel 2.

Tabel 2

Sebaran Responden menurut Kondisi Sosial Ekonomi dan Demografi

\begin{tabular}{lr}
\hline Sosial ekonomi dan demografi & $\mathbf{n}(\%)$ \\
\hline Umur (tahun) & $3362(59.0)$ \\
$20-40$ & $1779(31.2)$ \\
$41-60$ & $561(9.8)$ \\
$>60$ & $5702(100.0)$ \\
\hline Total & \\
\hline Pekerjaan utama & $564(9.9)$ \\
Tidak kerja/sekolah & $3248(57.0)$ \\
lbu rumah tangga & $764(13.4)$ \\
Pegawai UMN/swasta/PNS/TNI/Polri & $796(14.0)$ \\
Wiraswasta/ Pedagang/pelayanan jasa & $199(3.5)$ \\
Petani/nelayan/buruh & $131(2.3)$ \\
Lainnya & $5702(100.0)$ \\
\hline Total & \\
\hline Jenjang pendidikan & $897(15.8)$ \\
Tidak tamat SD & $1247(21.9)$ \\
Tamat SD & $1156(20.3)$ \\
Tamat SLTP & $1865(32.7)$ \\
Tamat SLTA & $537(9.4)$ \\
\hline Tamat perguruan tinggi & $5702(100.0)$ \\
\hline Total &
\end{tabular}




\begin{tabular}{lr} 
Pengeluaran per kapita/bulan & \\
Miskin (kuintil I dan II) & $2270(39.8)$ \\
Tidak miskin (kuintil III, IV, dan V) & $3432(60.2)$ \\
\hline Total & $5702(100.0)$ \\
\hline Status sosial ekonomi & \\
Rendah & $2270(39.8)$ \\
Tinggi & $3432(60.2)$ \\
\hline Total & $5702(100.0)$ \\
\hline
\end{tabular}

Pada Tabel 2 tampak bahwa lebih dari $60 \%$ sampel adalah ibu rumah tangga. Berdasarkan jenjang pendidikan, mayoritas sampel berpendidikan tamat SLTA. Berdasarkan pengeluaran per kapita per bulan, lebih dari setengah sampel terkategori tidak miskin. Status sosial ekonomi dalam penelitian ini ditentukan berdasarkan gabungan (komposit) tiga variabel yaitu pekerjaan utama, jenjang pendidikan dan pengeluaran per kapita/bulan, yang kemudian dikategorikan menjadi status sosial ekonomi tinggi dan status ekonomi rendah. Pada Tabel 2 juga tampak bahwa lebih dari setengah sampel memiliki status sosial ekonomi tinggi.

\section{Karakteristik Sampel menurut Status Gizi \\ Pada Tabel 3 tampak persentase terbesar status gizi sampel adalah obes diikuti normal, kurus dan terakhir gemuk. Sampel yang berstatus gizi obes sebanyak $48.1 \%$. Status gizi obes ditentukan berdasarkan perhitungan IMT dan lingkar perut.}

Tabel 3

Sebaran sampel berdasarkan status gizi

\begin{tabular}{lr}
\hline Status gizi & Jumlah $\mathbf{n}(\%)$ \\
\hline Kurus & $530(9.3)$ \\
Normal & $2213(38.8)$ \\
Gemuk & $215(3.8)$ \\
Obes (obesitas umum dan obesitas sentral) & $2744(48.1)$ \\
\hline Total & $5702(100.0)$ \\
\hline
\end{tabular}

Karakteristik Sampel menurut Gaya Hidup

Gaya hidup yang dimaksud di dalam penelitian ini meliputi kebiasaan konsumsi makanan berisiko, merokok, konsumsi alkohol dan gangguan mental emosional. Berikut adalah karakteristik sampel berdasarkan gaya hidup:

\section{Konsumsi Makanan Berisiko}

Makanan berisiko dalam penelitian ini antara lain: jeroan, makanan berlemak, makanan asin, makanan yang diawetkan, makanan/minuman manis, dan minuman berkafein. Berdasar kategori sering dan jarang, pada kedua kelompok sampel masing-masing konsumsi makanan berisiko pada umumnya terkategori jarang (Tabel 4). 
Tabel 4

Sebaran Sampel menurut Konsumsi Makanan Berisiko

\begin{tabular}{lr}
\multicolumn{1}{c}{ Perilaku berisiko } & \multicolumn{1}{c}{$\mathbf{n}(\%)$} \\
\hline Sering Konsumsi jeroan & $65(1.1)$ \\
Sering Konsumsi makanan berlemak & $383(6.7)$ \\
Sering Konsumsi makanan asin & $591(10.4)$ \\
Sering Konsumsi makanan yang diawetkan & $209(3.7)$ \\
Sering Konsumsi makanan/minuman manis & $1724(30.2)$ \\
Sering Konsumsi minuman berkafein & $517(9.1)$ \\
\hline
\end{tabular}

\section{Gangguan Mental Emosional}

Adanya gangguan mental emosional dinilai dengan Self Reporting Questionnaire (SRQ) yang terdiri dari 20 butir pertanyaan. Seseorang dikategorikan mengalami

gangguan emosional jika terhadap 20 pertanyaan kuesioner untuk kesehatan mental, minimal 6 pertanyaan dijawab 'ya'. Dalam penelitian ini sebanyak 24.0 persen sampel dikategorikan mengalami gangguan mental emosional (Tabel 5).

Tabel 5

Sebaran sampel menurut kondisi mental emosional

\begin{tabular}{lr}
\hline Kesehatan mental & Jumlah $\mathbf{n}(\%)$ \\
\hline Gangguan & $1370(24.0)$ \\
Tidak gangguan & $4332(76.0)$ \\
\hline Total & $5702(100.0)$ \\
\hline
\end{tabular}

\section{Kebiasaan Merokok}

Sebanyak 2.6 persen sampel memiliki kebiasaan merokok setiap hari. Pada wanita perokok, sebanyak 23.8 persen sampel pertama kali mulai merokok < umur 17 tahun. Berdasarkan jumlah batang rokok yang dihisap per hari, hanya 15 persen sampel perokok yang menghabiskan $\geq 15$ batang per hari. Berdasarkan jenis rokok yang dihisap, rokok kretek dengan filter adalah yang paling banyak dihisap perokok wanita $(60.7 \%)$ (Tabel 6).

Tabel 6

Sebaran sampel menurut kebiasaan merokok

\begin{tabular}{lr}
\hline Kebiasaan merokok & Jumlah $\mathbf{n}(\%)$ \\
\hline Merokok setiap hari & $147(2.6)$ \\
Merokok kadang-kadang & $153(2.7)$ \\
Sebelumnya pernah merokok & $84(1.5)$ \\
Tidak pernah merokok & $5318(93.3)$ \\
Usia pertama kali merokok < 17 th & $35(23.8)$ \\
Merokok $\geq 15$ batang/hari & $15(5.0)$ \\
Kretek tanpa filter & $54(18.0)$ \\
Rokok dengan filter & $182(60.7)$ \\
Rokok puth & $69(23.0)$ \\
Rokok linting & $17(5.7)$ \\
Cangklong & $1(0.3)$ \\
Cerutu & $14(4.7)$ \\
Tembakau kunyah & $14(4.7)$ \\
\hline
\end{tabular}




\section{Konsumsi Alkohol}

Berdasar frekuensi, sekitar 90 persen sampel menyatakan jarang mengkonsumsi alkohol. Berdasar jenis minuman, bir paling banyak dikonsumsi oleh sampel.

Tabel 7

Sebaran sampel menurut kebiasaan konsumsi alkohol

\begin{tabular}{lr}
\hline Konsumsi alkohol & Jumlah $\mathbf{n}(\%)$ \\
\hline Sering mengkonsumsi alkohol & $2(9.5)$ \\
Mengkonsumsi alkohol > 2 satuan & $3(14.3)$ \\
Bir & $9(42.9)$ \\
Whisky/vodka & $5(23.8)$ \\
Anggur/wine & $7(33.3)$ \\
Minuman tradisional & $0(0.00)$ \\
\hline
\end{tabular}

\section{Aktivitas Fisik dan Konsumsi Buah dan Sayur}

Lebih dari 75 persen terkategori tidak cukup melakukan aktivitas fisik (Tabel 8). Berdasarkan kecukupan konsumsi buah dan sayur, tidak ada satu pun sampel dalam penelitian ini yang terkategori cukup. Mayoritas sampel memiliki kebiasaan konsumsi $\geq 3$ hari per minggu, namun lebih dari 95 persen sampel mengkonsumsi buah dan sayur $<3$ porsi per hari (Tabel 8 ).

Tabel 8

Sebaran sampel menurut aktivitas fisik dan konsumsi buah sayur

\begin{tabular}{lc}
\hline \multicolumn{1}{c}{ Perilaku } & Jumlah $\mathrm{n}(\%)$ \\
\hline Aktivitas fisik tidak cukup & $4329(75.9)$ \\
Konsumsi buah dan sayur tidak cukup & $5132(100.0)$ \\
Konsumsi buah dan sayur < 3 hari/minggu & $825(14.5)$ \\
Konsumsi buah dan sayur < 3 porsi/hari & $5457(95.7)$ \\
\hline
\end{tabular}

Karakteristik Sampel menurut Kejadian Diabetes melitus

Sebanyak 2.9 persen sampel berstatus gizi tidak obes mengalami diabetes melitus

(D). Sementara sampel obes yang mengalami diabates melitus sebesar 2.1 persen (Tabel 9). Analisis kejadian diabetes melitus dipisahkan antara sampel yang berstatus gizi obes dan tidak obes.

Tabel 9

Sebaran sampel menurut kejadian diabetes melitus

Kejadian Diabetes mellitus Jumlah $\mathrm{n}(\%)$

Diabetes melitus pada sampel tidak obes (D) 165(2.9)

Diabetes mellitus pada sampel obes (DO) $119(2.1)$ 


\section{Hubungan Faktor Risiko dengan Diabetes Melitus}

Kejadian diabetes melitus lebih banyak terjadi pada usia $\geq 45$ tahun. Hubungan antara umur dengan diabetes melitus ( $D$ maupun DO) secara statistik signifikan $(p<0.05)$. Pada wanita dengan status gizi tidak obes, pada usia $\geq 45$ tahun risiko terkena diabetes melitus 10.38 kali lebih tinggi dibanding dengan usia < 45 tahun. Pada wanita obes risiko tersebut lebih tinggi yaitu 12.86 kali lebih tinggi dibanding yang berusia < 45 tahun. Hubungan diabetes melitus dengan kondisi sosial ekonomi tidak signifikan (Tabel 10).

Tabel 10

Hubungan Diabetes melitus dengan Kondisi Sosial Ekonomi dan Demografi

\begin{tabular}{|c|c|c|}
\hline Karakteristik & & Diabetes melitus \\
\hline & $\bar{D}$ & DO \\
\hline Umur $\geq 45$ th & $138(7.0)$ & $103(5.2)$ \\
\hline Umur < 45 th & $27(0.7)$ & $16(0.4)$ \\
\hline OR & $10.38(6.85-15.74)^{*}$ & $12.86(7.58-21.85)^{*}$ \\
\hline Sosek rendah & $64(2.8)$ & $49(2.2)$ \\
\hline Sosek tinggi & $101(2.9)$ & $70(2.0)$ \\
\hline OR & $0.96(0.70-1.31)$ & $1.06(0.73-1.53)$ \\
\hline $\begin{array}{ll}\text { Keterangan: } & \\
\mathrm{D} & =\text { diabetes } \\
\mathrm{DO} & =\text { diabetes } \\
& \\
& =\text { hubung }\end{array}$ & $\begin{array}{l}\text { ada sampel tidak obes } \\
\text { ada sampel obes } \\
\text { an }(p<0.05)\end{array}$ & \\
\hline
\end{tabular}

Berdasar status gizi dengan Sampel yang berstatus gizi obes berisiko perhitungan Indeks Massa Tubuh (IMT) dan terkena diabetes melitus 2.93 kali lebih besar lingkar perut, proporsi kejadian diabetes dibandingkan status gizi normal, melitus pada sampel obes lebih tinggi dibanding sampel tidak obes (Tabel 11). $\mathrm{OR}=2.93(1.94-4.41)$.

Tabel 11

Hubungan Status Gizi (IMT dan lingkar perut) dengan Diabetes melitus

\begin{tabular}{lc}
\hline & Diabetes Melitus \\
\hline Status Gizi & $\mathbf{D}$ \\
& $\mathbf{n}(\%)$ \\
\hline Kurus & $11(1.9)$ \\
\hline Normal & $77(2.4)$ \\
\hline OR & $0.79(0.41-1.49)$ \\
\hline Gemuk & $28(3.6)$ \\
Normal & $77(2.4)$ \\
\hline OR & $1.47(0.95-2.28)$ \\
\hline Obes & $119(9.9)$ \\
Normal & $77(2.4)$ \\
\hline OR & $\mathbf{2 . 9 3 ( 1 . 9 4 - 4 . 4 1 ) ^ { * }}$ \\
\hline
\end{tabular}




\section{Konsumsi Makanan Berisiko}

Proporsi kejadian diabetes melitus antara sampel yang sering mengkonsumsi makanan/minuman berisiko dengan yang jarang mengkonsumsinya pada umumnya tidak terlalu berbeda. Pada Tabel 12 disajikan nilai $\mathrm{OR}$ antara sampel yang jarang mengkonsumsi makanan berisiko dibandingkan dengan sampel yang sering mengkonsumsinya. Kebiasaan konsumsi makanan/minuman manis memiliki hubungan signifikan dengan kejadian diabetes melitus, baik pada sampel obes maupun tidak obes.

Tabel 12

Hubungan Konsumsi Makanan Berisiko dengan Diabetes melitus

\begin{tabular}{lcc}
\hline \multicolumn{3}{c}{ Diabetes Melitus } \\
\hline Kebiasaan Makan & $\begin{array}{c}\mathbf{D} \\
\mathbf{n}(\%)\end{array}$ & $\begin{array}{c}\mathbf{D} 0 \\
\mathbf{n}(\%)\end{array}$ \\
\hline OR makan jeroan & $1.07(0.26-4.39)$ & $0.67(0.16-2.76)$ \\
\hline OR makan berlemak & $0.70(0.34-1.44)$ & $1.16(0.53-2.50)$ \\
\hline OR makan asin & $0.99(0.60-1.65)$ & $1.14(0.61-2.13)$ \\
\hline OR makan awetan & $0.48(0.15-1.51)$ & $2.25(0.55-9.18)$ \\
\hline OR makan manis & $\mathbf{2 . 4 8 ( 1 . 3 2 - 4 . 7 2 ) ^ { * }}$ & $\mathbf{2 . 6 4 ( 1 . 5 8 - 4 . 4 3 ) ^ { * }}$ \\
\hline OR minum kafein & $0.50(0.25-1.03)$ & $1.39(0.68-2.87)$ \\
\hline
\end{tabular}

\section{Merokok}

Riwayat merokok di masa lalu berhubungan signifikan dengan kejadian diabetes melitus baik pada sampel obes maupun tidak obes (D dan DO) (Tabel 13). Pada wanita tidak obes, kebiasaan merokok di masa lalu memiliki risiko terkena diabetes melitus 2.63 kali lebih tinggi dibanding wanita yang tidak merokok. Sementara pada wanita obes risiko tersebut lebih besar lagi yaitu 3.05 kali antara sampel dengan riwayat merokok di masa lalu dibanding sampel yang tidak merokok.

Tabel 13

Hubungan Merokok dengan Diabetes melitus

\begin{tabular}{lrr}
\hline & & Diabetes melitus \\
\hline Riwayat Merokok & $\begin{array}{r}\mathrm{D} \\
\mathrm{n} \mathrm{( \% )}\end{array}$ & $\begin{array}{r}\mathrm{DO} \\
\mathrm{n}(\%)\end{array}$ \\
\hline OR Setiap hari merokok & $0.96(0.35-2.62)$ & $1.01(0.32-3.20)$ \\
\hline OR Merokok kadang-kadang & $0.92(0.34-2.51)$ & $0.96(0.30-3.07)$ \\
\hline OR Pernah merokok & $\mathbf{2 . 6 3 ( 1 . 1 3 - 6 . 1 3 ) ^ { * }}$ & $\mathbf{3 . 0 5 ( 1 . 2 1 - 7 . 6 9 ) ^ { * }}$ \\
\hline OR Merokok $\geq 17$ tahun & $0.30(0.40-2.21)$ & $0.15(0.01-1.69)$ \\
\hline OR Merokok $\geq 15$ batang/hr & - & - \\
\hline OR Rokok kretek tanpa filter & $0.65(0.09-4.70)$ & $0.91(0.12-6.64)$ \\
\hline OR Rokok filter & $0.97(0.39-2.39)$ & $0.81(0.25-2.57)$ \\
\hline OR Rokok putih & $1.02(0.25-4.21)$ & $1.44(0.35-5.95)$ \\
\hline OR Rokok linting & - & - \\
\hline OR Cangklong & - & - \\
\hline
\end{tabular}




\begin{tabular}{lrr}
\hline OR Cerutu & $2.63(0.34-20.25)$ & $3.71(0.48-28.62)$ \\
\hline OR Tembakau kunyah & $2.63(0.34-20.25)$ & $3.71(0.48-28.62)$ \\
\hline OR rokok putih vs non putih & $0.60(0.07-4.98)$ & $0.85(0.10-7.42)$ \\
\hline $\begin{array}{l}\text { OR rokok puth+filter vs non } \\
\text { putih+filter }\end{array}$ & $1.07(0.21-5.40)$ & $1.61(0.29-9.10)$ \\
\hline
\end{tabular}

\section{Konsumsi Minuman Beralkohol}

Penderita diabetes melitus di dalam penelitian ini tidak ada yang memiliki kebiasaan mengkonsumsi alkohol dalam satu bulan terakhir, sehingga tidak bisa dianalisis hubungan konsumsi alkohol dengan kejadian diabetes melitus

\section{Gangguan Mental Emosional}

Proporsi kejadian diabetes melitus lebih banyak terjadi pada sampel yang mengalami gangguan mental emosional dibanding dengan sampel yang tidak mengalami gangguan mental emosional (normal) (Tabel 14). Gangguan mental emosional berhubungan signifikan dengan diabetes melitus, baik pada sampel obes maupun tidak obes. Pada wanita tidak obes yang mengalami gangguan mental emosional memiliki risiko terkena diabetes melitus 1.61 kali lebih tinggi dibanding dengan yang tidak mengalami gangguan. Sementara pada wanita obes, risiko tersebut lebih tinggi yaitu sebesar 1.62 kali.

Tabel 14

Hubungan Kondisi Mental Emosional dengan Diabetes melitus

\begin{tabular}{lrr}
\hline Mental Emosional & & Diabetes melitus \\
& $\mathrm{D}$ & $\mathrm{DO}$ \\
& $\mathrm{n}(\%)$ & $\mathrm{n}(\%)$ \\
\hline Gangguan & $55(4.0)$ & $40(2.9)$ \\
\hline Tidak gangguan & $110(2.5)$ & $79(1.8)$ \\
\hline OR & $1.61(1.15-2.23)^{*}$ & $1.62(1.10-2.38)^{*}$ \\
\hline
\end{tabular}

\section{Aktivitas Fisik dan Konsumsi Buah dan} Sayur

Pada Tabel 15 tampak bahwa hubungan kebiasaan konsumsi buah dan sayur serta kebiasaan aktivitas fisik tidak berhubungan signifikan dengan kejadian diabetes melitus pada wanita.

Tabel 15 Hubungan Aktivitas Fisik dan Konsumsi Buah dan Sayur dengan Diabetes melitus

\begin{tabular}{lcr}
\hline & Diabetes mellitus \\
\hline & $\mathbf{D}$ & DO \\
Perilaku & $\mathrm{n}(\%)$ & $\mathbf{n}(\%)$ \\
\hline OR Kons. Buah sayur tdk cukup & - & - \\
\hline OR Kons. Buah sayur $\geq 3 \mathrm{hr} / \mathrm{mg}$ & $1.11(0.82-1.52)$ & $0.65(0.26-1.60)$ \\
\hline OR Buah sayur $\geq 3$ porsi/hr & $0.99(0.46-2.13)$ & $0.67(0.43-1.03)$ \\
\hline OR Aktv. Fisik tidak cukup & $1.18(0.81-1.73)$ & $1.14(0.73-1.76)$ \\
\hline
\end{tabular}

\section{Faktor Risiko Diabetes Melitus}

Setelah menganalisis beberapa faktor risiko diabetes melitus secara bersama- sama, maka ditemukan beberapa faktor risiko yang berhubungan signifikan $(p<0.05)$. 
Hasil analisis regresi logistik dari beberapa faktor risiko disajikan dalam Tabel 16.

Tabel 16

Faktor-faktor Risiko Diabetes Melitus

\begin{tabular}{|c|c|}
\hline Faktor risiko & OR \\
\hline Umur $\geq 45$ tahun (DO) & $13.0(7.5-22.5)^{*}$ \\
\hline Umur $\geq 45$ tahun (D) & $9.3(5.8-15.1)^{*}$ \\
\hline Merokok di masa lalu (D) & $2.4(0.9-5.8)$ \\
\hline Gangguan emosional (D) & $1.4(0.9-2.1)$ \\
\hline Gangguan emosional (DO) & $1.4(0.9-2.1)$ \\
\hline Jarang kons. makanan/minuman manis (D) & $0.4(0.3-0.7)^{*}$ \\
\hline Jarang kons. makanan/minuman manis (DO) & $0.4(0.2-0.6)^{*}$ \\
\hline
\end{tabular}

\section{BAHASAN}

Pada penelitian ini, umur $\geq 45$ tahun pada sampel obes ataupun tidak obes memiliki risiko terkena diabetes melitus lebih besar dibanding yang berumur $<45$ tahun. Setelah mengontrol seluruh faktor risiko lainnya, maka dalam penelitian ini tampak bahwa pada wanita obes, kelompok umur $\geq$ 45 tahun berisiko 13.0 kali lebih besar daripada kelompok umur < 45 tahun, $\mathrm{OR}=13.0(7.5-22.5)$. Pada wanita tidak obes risiko tersebut sebesar 9.3 kali, OR=9.3(5.815.1).

Menurut Soegondo (2002), salah satu faktor yang berisiko tinggi terkena diabetes melitus adalah mereka yang berusia $>40$ tahun. Soegondo juga menambahkannya dengan faktor penyerta riwayat keluarga dengan diabetes melitus dan berstatus gizi lebih (gemuk atau obes) sebagai faktor risiko diabetes melitus?.

Sering mengkonsumsi makanan/minuman manis menjadi faktor risiko diabetes melitus pada wanita baik yang berstatus gizi obes maupun tidak obes. Wanita baik obes maupun tidak obes yang jarang mengkonsumsi makanan/minuman manis memiliki risiko terkena diabetes melitus sekitar $60 \%$ lebih kecil dibanding yang sering mengkonsumsinya, $\mathrm{OR}=0.4(0.2-$ 0.6) dan $\mathrm{OR}=0.4(0.3-0.7)$. Pada penderita penyakit diabetes melitus, metabolisme karbohidrat terganggu sebagai akibat terganggunya produksi hormon insulin oleh pankreas. Defisiensi insulin menyebabkan tidak semua glukosa dapat diubah menjadi glikogen. Ini berarti sebagian glukosa yang berasal dari makanan tetap berada dalam darah. Tingginya kadar gula darah (hiperglikemia) akan mendorong pembuangan kelebihan glukosa tersebut keluar tubuh melalui urin. Hal inilah yang menyebabkan terjadinya glikosuria.

Dengan sedikitnya glukosa yang dapat diubah menjadi glikogen, maka untuk memenuhi kebutuhan energi otot akan terjadi pengubahan glikogen hati menjadi glukosa melalui jalur glukoneogenesis. Jadi tingginya kadar glukosa dalam darah selain berasal dari glukosa makanan yang tidak dapat diubah menjadi glikogen oleh tubuh, juga berasal dari proses glukoneogenesis yang masuk ke peredaran darah (Moehyi, 1997) ${ }^{10}$. Hilangnya sebagian besar glukosa karena tidak dapat digunakan tubuh dan terbuangnya melalui urin membawa akibat terbawanya lemak tubuh (lipolisis) dan protein (proteolisis) untuk dijadikan sumber energi. Digunakannya asam lemak sebagai sumber energi akan menyebabkan terbentuknya zat keton yang terdiri dari asam asetoasetat betahidroksi butirat dan aseton. Kurangnya insulin dalam tubuh dapat menyebabkan jumlah zat keton yang tertumpuk dalam darah melebihi kemampuan 
tubuh untuk memecahnya dan penderita akan mengalami keracunan zat keton yang disebut ketoasidosis (Wetherhill dan Dean, 2001 $)^{11}$. Makanan/minuman manis merupakan makanan sumber energi. Sering mengkonsumsi makanan/minuman manis bisa menyebabkan seseorang mengalami overnutrition. Sementara overnutrition merupakan salah satu faktor penyebab diabetes melitus. Semakin lama dan semakin berat obesitas seseorang, maka semakin besar.

\section{KESIMPULAN}

Hasil analisis multivariat menunjukkan bahwa faktor-faktor risiko diabetes melitus pada pria dewasa antara lain umur $\geq 45$ tahun pada wanita obes maupun tidak obes serta kebiasaan konsumsi makanan/minuman manis baik pada wanita obes maupun tidak obes.

\section{RUJUKAN}

1. World Health Organization. International Statistical Classification of Diseases and Related Health Problem. Edisi 10 (ICD-10). Geneva: World Health Organization, 2003

2. Tim Survei Kesehatan Nasional Nasional. 2002. Studi Morbiditas dan Disabilitas, Laporan Survei Kesehatan Rumah Tangga (SKRT) 2001. Jakarta: Badan Penelitian dan Pengembangan Kesehatan Departemen Kesehatan Republik Indonesia.

3. American Diabetes Association. 2004. Global prevalence of diabetes: estimates for the year 2000 and projections for 2020. Diabetes Care.

4. Departemen Kesehatan. 2002. Laporan survei kesehatan rumah tangga (SKRT) 2001. Studi Morbiditas dan Disabilitas. Jakarta: Depkes.

5. Departemen Kesehatan. 2004. Laporan survei kesehatan rumah tangga (SKRT) 2003. Studi Morbiditas dan Disabilitas. Jakarta: Depkes.

6. Departemen Kesehatan. 2008. Laporan hasil riset kesehatan dasar Indonesia Tahun 2007. Jakarta: Depkes.

7. Departemen Kesehatan. 1996. Pedoman Praktis Memantau Status Gizi Orang Dewasa. Direktorat Gizi Masyarakat. Departemen Kesehatan RI, Jakarta.

8. World Health Organization. 2005. Surveillance of Major Noncommunicable Diseases in South-East Asia Region, Report of an Inter-country Consultation. Geneva: World Health Organization.

9. Soegondo. 2002. Diagnosis dan Klasifikasi Diabetes Melitus Terkini. Di dalam: Soegondo S, Soewondo P, dan Subekti I, editor. Penatalaksanaan Diabetes Melitus. Jakarta: Fakultas Kedokteran Universitas Indonesia.

10. Moehyi S. 1997. Pengaturan Makanan dan Diit untuk Penyembuhan Penyakit. Jakarta: PT Gramedia Pustaka Utama.

11. Wetherill D dan Kerelakes DJ. 2001. Diabetes. Jakarta: Elex Media Komputindo. 